\title{
Employing infographics based on Tablet Applications to Improve Professional Competence in the light of the Digital Transformation of Education Technology Specialists
}

\author{
Dr. Amir Shahin \\ Digital Design and Publishing Research Unit (DDPRU), \\ Faculty of Education, \\ Tanta University, Egypt
}

\begin{abstract}
The current research aims at employing infographics based on tablet applications to improve professional competence in the light of the digital transformation of educational technology specialist's .Tools of the research were a test of the cognitive aspects of the professional competence and a note card of the performance. The study sample included (20) teachers working for governmental schools. The study concluded that there is a statistical significance for both the cognitive aspect test and the performance note card for education technology aspects. The study also recommended employing infographics based on tablet applications while training teachers before and during taking their jobs for its effective impact.
\end{abstract}

Keywords: infographics,tablet applications, digital transformation, professional competence, Education Technology Specialists

\section{Introduction}

Technological development has contributed greatly to change the way of using environments based on web which helped to upgrade these content of the school curriculum (Karaman, Yildirim \& Kaban, 2008). Atici and Yildirim, 2010 argued that users of web environments could produce electronic data, which become greatly used nowadays. One of these web tools is infographics which turns complicated data into a decorated and designed ones (Harrison, lane, Katharina Reineke, and Remco change, 2015). Infographics is widely used especially in education field in which students and teachers present their drawings and designs. Recently, modern technology made it available to teach designing in 3 ways: by using webs, classical ways and currently the infographics whose usage becomes so important to serve a pleasant style for drawings. This task needs a general knowledge from the designer and education technology specialist (Gao \& Ming, 2014) to gain extra skills while teaching subjects in classes. After that technological change, it became clear that many Arab countries complain about the shortage of teachers at schools and their degraded cultural and scientific backgrounds.

This is the conclusion of the results of his study(Wael, 2005) confirmed that the problems in the Arab countries result from the ways of rehabilitating teachers who lack in practice and motivation. Mosood compared the previous roles teachers play in their educational institutions to the future roles they should play. That means we are in a bad need to a radical change in the policy of preparing the teachers in Arab countries in addition to getting rid of the old methods which supported memorizing and directing (Gomana 2006). Professional competence can be classified into 4 fields (Saleh, 2000): teaching competence class, management competence, class communication and activity competence. Other studies (shahin, \& Essam ,2019) and study (Malek \&Assem, 2019 ) confirmed that it is necessary for schools to have an educational technology specialist to cope with the $21^{\text {st }}$ century skills and the $4^{\text {th }}$ industrial revolution to achieve the digital transformation ; the process which seeks to change producing and distributing ways of the previous old services via replacing the tangible elements with virtual ones such as ways of contacting students, ways of designing services and knowing persons who benefit from 
these services online besides replacing the physical interaction processes with electronic ones such as video conferences and distant learning. Moreover, concrete individual tasks should be replaced with virtual ones (BBaghani, Ashokb. \& Taborzki, Maria, 2007).

\section{Methodology}

The recent research tried to answer the main question: employing smart phone applications based on infographics to improve the professional competence in the light of digital transformation for educational technology specialists? There are also sub questions in this aspect :

1- What is the educational design suitable for employing based - on - infographics smart phone applications to improve the professional competence in the light of digital transformation for educational technology specialists?

2- What is the effect of employing the based-oninfographics smartphone applications on improving the professional competence in the light of digital transformation for educational technology specialists?

3- What is the effect of employing the based-oninfographics smartphone applications on improving the professional competence in the light of digital transformation for educational technology specialists for the first experimental group?

4- What is the effect of employing the based-oninfographics smartphone applications on improving the professional competence in the light of digital transformation for educational technology specialists for the second experimental group?

\section{Aims of the research:}

The research tries to know:

1- The suitable educational design to employ smartphone applications based on infographics to improve the professional competence in the light of digital transformation for educational technology specialists.

2- To know the difference between moving info graphic and interactive one by using smart phone apps.

3- To know the skills and information required for improving the professional competence for educational technology specialists.

\section{Research importance:}

The research importance can be summarized in the following points:
1- It is a step to upgrade the competence of educational technology specialist in order to undertake his responsibility and scientific mission successfully in that rapidly changed age.

2- Enabling educational technology specialists to develop themselves to be able to become employable during their life.

3- It is a try to .help specialists to present a new style while introducing their subject and school content in an attractive way.

4- It is a new addition containing a list of productive mental habits to which school's curriculum should stick generally and students of faculty of education particularly.

\section{Objective limits of the research:}

The researcher formed his study sample from 20 development specialists( 2018/2019 )who are divided into 2 groups in order to employ info graphics:

1- The first experimental group contained 10 technological development specialists who studied the moving info graphics. Specialists use tablet applications.

2- The second experimental group contained 10 technological development specialists who studied the interactive info graphics. Specialists use tablet applications.

That study belongs to the developmental researches in which the researchers used the descriptive method, the analytic method and the sub experimental method to design the educational content and employ the info graphics.

The current research used some criteria required to employ info graphics; the criteria which were authorized by specialists in the field of educational technology.

The researcher resorted to use the educational design model (ADDIE), accumulative test and a performance note card to measure the pre and post application for the 2 experimental groups the researcher tried to carry out .The following strategy.

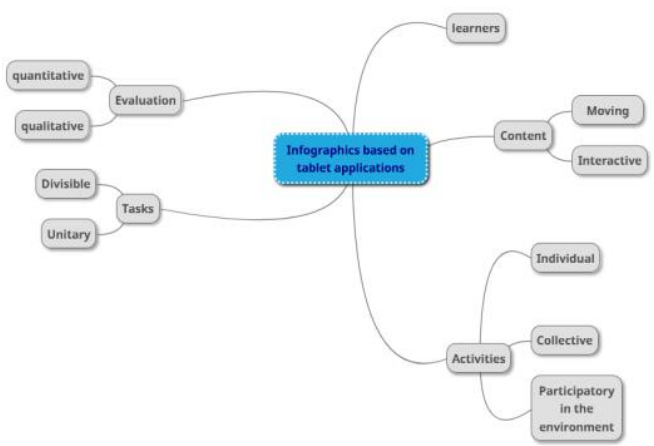

Fig. 1. Strategy employing infographics based on tablet applications Result 


\section{Result}

The researcher used Mann -Whitney test to calculate the significance of differences between means of students' grades of the pre and post application for the experimental group as follows:

Table 1. The value of Mann - Whitney test (achievement and observing performance) in post application.

\begin{tabular}{|l|l|l|l|l|l|l|}
\hline Research tools & Groups & $\mathbf{N}$ & Mean & $\begin{array}{l}\text { Mean } \\
\text { Rank }\end{array}$ & $\begin{array}{l}\text { Sum of } \\
\text { Ranks }\end{array}$ & Z \\
\hline \multirow{3}{*}{ Achievement } & Moving & 10 & 15.5 & 5.50 & 55.00 & \multirow{2}{*}{4.00} \\
\cline { 2 - 6 } & Interactive & 10 & 19.70 & 15.50 & 155.00 & \\
\hline \multirow{2}{*}{$\begin{array}{l}\text { Observing } \\
\text { performance }\end{array}$} & Moving & 10 & 18.5 & 5.60 & 56.00 & \multirow{2}{*}{3.742} \\
\cline { 2 - 6 } & Interactive & 10 & 23.5 & 15.40 & 154.00 & \\
\hline
\end{tabular}

*Significance (0.01)

The previous table shows that $\mathrm{z}$ value has a statistical significance. As for arithmetic means of the experimental group, it is clear that the mean of the cognitive aspect test for the second experimental group which studied the interactive infographics was (19.70) a value which is higher than the mean of the first group which studied the moving infographics. Meanwhile, the mean of the performance note card was 23, 5; a value which is higher than the mean of the first group.

\section{Discussion}

It is clear that the interactive infographics was more effective than the moving ones and helped to improve the professional competence in the light of the digital transformation for the educational technology specialists; the thing which helped the learners to employ their time and skills in improving study environment, so it is preferable for specialists in education technology to depend greatly on interactive infographics at their schools and universities. Moreover, info graphic technology helped greatly in making the study sample individuals able to use digital transformation skills by focusing on product rather than the project .In other words, it is important to focus on the general task rather than the particulars. Also, it is important for specialists of education technology to focus greatly on showing their personal skills more than showing the content. These skills are creation, ability to learn and involving in study.

\section{Conclusion:}

Infographics helped to deepen the concept of the digital transformation and the professional competence to help in managing, planning, analyzing and supporting information. Thus, there are essential skills specialists in education technology must have to go on along the 21 th century.

\section{Recommendations:}

It is recommended to increase using the modern techniques in the educational technology and training teachers and specialists to employ infographics in the various fields such as learning and teaching besides seeking to develop school curriculum. It is also recommended to use the (2D) (3D), dimensions of infographics and made it available for teachers and professors.

\section{References}

[1] Saleh, Al-Azraq (2000): Educational Psychology for Teachers, Theoretical Concepts. Dar Al-Fikr Al-Arabi and Tripoli International Scientific Library. Libya. First edition.

[2] Atici, B., \& Yildirim, S. (2010). Web 2.0 Uygulamalarının EÖğrenmeye Etkisi. Akademik Bilişim2010, 10-12. 02.2010. Mugla, Turkey.

[3] BBoghani, Ashok B. and Taborzki, Maria,( 2007)Physical to Digital Transformation: Any New Opportunities, New York, Monitor Group, p.1.

[4] Gao, R., \& Ming, Y. Z. (2014). Infographics applied in design education. In 2014 IEEE Workshop on Advanced Research and Technology in Industry Applications (WARTIA)(pp. 984986).Ottawa: IEEE.

[5] Harrison, Lane, Katharina Reinecke, and Remco Chang(2015) "Infographic Aesthetics." Proceedings of the 33rd Annual ACM Conference on Human Factors in Computing Systems - CHI '15 (2015). doi:10.1145/2702123.2702545.

[6] Karaman, S., Yildirim, S., \& Kaban, A. (2008). Öğrenme 2.0 yaygınlaşıyor: web 2.0 uygulamalarının eğitimde kullanımına ilişkin araştırmalar ve sonuçları. inet-tr'08 - XIII. Türkiye'de İnternet Konferansı Bildirileri 22-23 Aralık 2008 Orta Doğu Teknik Üniversitesi, Ankara

[7] Malik ,Khaled\& Assem, Dina (2019), the educational management competencies and educational technology necessary for professional learning societies in light of the skills of the twenty-first century and the fourth industrial revolution, studies in university education, $\mathrm{p}$ 44, Center for University Education Development, Faculty of Education, Ain Shams University, p. 74 198.

[8] Wael, Masoud (2005): The role of the teacher in special education institutes and programs in the Kingdom of Saudi Arabia. The Arab Journal of Special Education, No. 6. pp. 77-114

[9] Jumana, Obaid (2006): The Teacher: Preparation, Training, and Competencies: First Edition. Safa House for Publishing and Distribution Amman.

[10] Shahin, Amir \& Essam,M (2019) The Role Of Specialized Incubators In The Field Of Educational Technology In Supporting Innovation And Achieving Sustainable Development In The Sinai, Conference: Research Presented To The Fifth International Scientific Conference, "Specific Learning And Its Role In Developing Projects For The Development Of The Sinai, At AlShabab City, Sharm El-Sheikh 